\title{
Analisis Unjuk kerja Jaringan Microcell LTE Berdasarkan Variasi Level Modulasi
}

\author{
Shafira Fajrin Arumsidi ${ }^{1}$, Anggun Fitrian Isnawati ${ }^{2}$, Ade Wahyudin ${ }^{3}$ \\ ${ }^{1,2}$ Institut Teknologi Telkom Purwokerto \\ ${ }^{3}$ Sekolah Tinggi Multimedia Yogyakarta \\ Jl. D.I Panjaitan No.128 Purwokerto, Indonesia \\ Email : shafirafajrinarumsidi@gmail.com, anggun@ittelkom-pwt.ac.id
}

\begin{abstract}
The development of telecommunications technology continues to increase, especially in the use of cellular communication networks. Users of cellular networks today need high-speed communication to be able to enjoy the facilities offered such as streaming video, web browsing, e-mail and others. With the current increase in user capacity, it causes a lot of interference. Therefore, the use of modulation techniques needs to be considered. To find out the proper use of modulation, in accordance with the conditions of the region and the network used, this study examines the performance of variations in modulation levels, namely QPSK, 16QAM, 64QAM and 256QAM. The parameters measured in this study include RSRP, CINR, BER, user connected and throughput. Based on the coverage by RSRP simulation results, it was found that the RSRP did not change because the power signal will always adjust to any use of the modulation level. For coverage by CINR obtained to obtain a higher rate value, a higher CINR value is needed and for coverage by BER parameters, BER does not affect the bit per symbol carried by each modulation, only affects the different types of modulation. Meanwhile, in the capacity by Throughput parameter, QPSK modulation produces the lowest average throughput value of $14.01 \mathrm{Mbps}$ followed by 16QAM 21.58 Mbps 64QAM 28.6 Mbps and 256QAM 33.87 Mbps. In addition, for the capacity by user connected parameters all connected users on all modulation used will produce $100 \%$ for capacity by user connected.
\end{abstract}

Keywords: Modulation, RSRP, CINR, BER, throughput, user connected

\begin{abstract}
Abstrak
Perkembangan teknologi telekomunikasi saat ini terus mengalami peningkatan, terutama pada pemakaian jaringan komunikasi seluler. Pengguna jaringan seluler saat ini membutuhkan komunikasi berkecepatan tinggi untuk dapat menikmati fasilitas yang ditawarkan seperti streaming video, web browsing, email dan lain-lain. Dengan meningkatnya kapasitas user saat ini, menyebabkan banyak terjadinya interferensi. Maka dari itu, penggunaan teknik modulasi perlu diperhatikan. Untuk mengetahui penggunaan modulasi yang tepat, sesuai dengan kondisi wilayah dan jaringan yang digunakan maka pada penelitian ini meneliti performansi variasi level modulasi yakni QPSK, 16-QAM, 64QAM dan 256-QAM penelitian ini dilakukan pada jaringan microcell dengan mengguakan software Atoll. Parameter yang diukur pada penelitian ini meliputi RSRP, CINR, BER, user connected dan throughput. Berdasarkan hasil simulasi coverage by RSRP didapatkan
\end{abstract}


hasil bahwa RSRP tidak mengalami perubahan karena daya sinyal akan selalu menyesuaikan dengan berapapun penggunaan level modulasi. Untuk coverage by CINR didapatkan untuk mendapatkan nilai datarate yang lebih tinggi maka diperlukan nilai CINR yang lebih tinggi dan untuk parameter coverage by BER, BER tidak berpengaruh pada bit per simbol yang dibawa oleh masing-masing modulasi hanya saja berpengaruh pada jenis modulasi yang berbeda. Sedangkan pada parameter capacity by Throughput, modulasi QPSK menghasilkan rata-rata nilai throughput yang paling rendah yaitu 14,01 Mbps kemudian dengan 16-QAM 21,58 Mbps, 64-QAM 28,6 Mbps dan 256-QAM 33,87 Mbps. Selain itu, untuk parameter capacity by user connected semua user teroneksi pada semua modulasi yang digunakan maka dihasilkan $100 \%$ untuk capacity by user connected.

Kata kunci: Modulasi, RSRP, CINR, BER, throughput, user connected

\section{Pendahuluan}

Perkembangan teknologi telekomunikasi saat ini terus mengalami peningkatan, terutama pada pemakaian jaringan komunikasi seluler. Pengguna jaringan seluler saat ini membutuhkan komunikasi berkecepatan tinggi untuk dapat menikmati fasilitas yang ditawarkan seperti streaming video, web browsing, email dan lain-lain [1]. Untuk memenuhi komunikasi dengan laju data yang tinggi, kapasitas yang besar dan mobilitas yang tinggi di manapun user berada, baik di dalam gedung (indoor) atau di luar gedung (outdoor). Teknologi Long Term Evolution (LTE) merupakan pengembangan dari teknologi UMTS (3G) dan HSPDA (3,5G) yang memiliki kecepatan uplink sebesar 50 Mbps dan downlink 100 Mbps [2]. Pada implementasinya, teknologi LTE mampu meningkatkan kualitas layanan yang dibutuhkan dalam menghadapi perkembangan jumlah user. Akan tetapi, terdapat permasalahan lain yang belum ditangani yakni permasalahan utama yang dihadapi operator terkait keterbatasan bandwidth. Untuk mengatasi masalah tersebut 3GPP berhasil mengembangkan LTE menjadi LTE-Advanced. LTEAdvanced mendukung fitur carrier aggregation yakni teknik pengunaan dua atau lebih band frekuensi secara bersamaan pada rentang frekuensi yang sama ataupun berbeda untuk mengatasi masalah utama yang dihadapi oleh operator.

Dengan meningkatnya kapasitas user saat ini, menyebabkan banyak terjadinya interferensi. Maka dari itu, penggunaan teknik modulasi perlu diperhatikan. Modulasi yaitu proses dimana perubahan suatu gelombang periodik sehingga dapat menjadikan suatu sinyal yang dapat membawa suatu informasi, tanpa adanya modulasi suatu informasi tidak dapat dikirim. Penggunaan modulasi sesuai dengan kondisi kanal di wilayah dan jaringan yang digunakan.

Untuk mengetahui penggunaan modulasi yang tepat, sesuai dengan kondisi wilayah dan jaringan yang digunakan maka pada penelitian ini meneliti performansi variasi level modulasi pada jaringan microcell. Pada penelitan ini menggunakan software simulasi Atoll. Atoll merupakan software radio planning yang menyediakan fitur-fitur yang komperhensif dan terpadu sehingga dapat digunakan 
AITI: Jurnal Teknologi Informasi

untuk membuat proyek perencanaan microwave ataupun perencanaan radio dalam satu aplikasi [3]. Penggunaan modulasi, berdasarkan kondisi sinyal antara pengguna dan pemancar. Untuk menghadapi kondisi sinyal yang kurang baik maka memakai teknik modulasi yang tahan terhadap gangguan sebaliknya untuk kondisi sinyal yang baik maka digunakan teknik modulasi yang mengandung informasi lebih banyak.

Pada penelitian yang berjudul "Perancangan Jaringan Mikrosel 4G LTE di Skywalk Cihampelas Bandung" meneliti mengenai perancangan jaringan microcell untuk meningkatkan kualitas jaringan LTE di Skywalk Cihampelas, dengan menggunakan metode Automatic Cell Planning (ACP) dan non Automatic Cell Planning. Penelitian ini menggunakan frekuensi $1800 \mathrm{MHz}$ dengan parameter RSRP, RSSI, SINR dan BLER.

Berdasarkan hasil simulasi Atoll didapatkan 2 jumlah site. Hasil ini menunjukkan bahwa dengan menggunakan metode ACP dapat mengoptimalkan site yang sudah dirancang dan hasilnya lebih bagus sekitar $20 \%$ dibanding dengan yang tidak menggunakan ACP. Parameter RSRP ketika disimulasi dengan non ACP mendapatkan hasil sebesar -105,42 dBm, tetapi ketika menggunakan simulasi ACP hasilnya lebih baik yaitu mendapatkan nilai sebesar $-86,1 \mathrm{dBm}$, sehingga dapat memenuhi standar KPI operator yang mensyaratkan RSRP sebesar >-90 dBm. Parameter RSSI dengan non ACP mendapatkan hasil sebesar -70,06 dBm, tetapi ketika menggunakan simulasi ACP hasilnya semakin baik yaitu mendapatkan nilai sebesar -50,1 dB sehingga bisa memenuhi standar KPI operator sebesar >-70 dBm. Parameter SINR berdasarkan hasil drive test sebesar $-4,75 \mathrm{~dB}$ ketika disimulasi dengan non ACP mendapatkan hasil sebesar 10,25 dB, tetapi ketika menggunakan simulasi ACP hasilnya semakin lebih baik yaitu mendapatkan nilai sebesar 34,5 dB, sehingga dapat memenuhi standar KPI operator sebesar $>10 \mathrm{~dB}$. Parameter BLER dengan non ACP mendapatkan hasil sebesar $0 \%$ tetapi ketika menggunakan simulasi ACP hasilnya semakin lebih baik yaitu mendapatkan nilai sebesar $0 \%$, sehingga dapat memenuhi standar KPI operator sebesar $<10 \%$. Pada simulasi trafik ini yang gagal terkoneksi pada simulasi persentasenya tergolong rendah yakni sebesar 9,5\% sedangkan trafik yang berhasil tergolong tinggi yaitu sebesar $90,5 \%$ [4].

Untuk mengakomodasi terjadinya perubahan kanal maka pada penelitian ini digunakan beberapa level modulasi yakni QPSK, 16-QAM, 64-QAM dan 256QAM. Berdasarkan latar belakang tersebut penulis mengambil judul penelitian mengenai “Analisis Unjukkerja Jaringan Microcell LTE Berdasarkan Variasi Level Modulasi“. Parameter yang diukur pada penelitian ini yaitu RSRP, CINR, BER, user connected dan throughput. 


\section{Metode Penelitian}

Penelitian ini menggunakan suatu software simulasi dalam menganalisis kinerja pada masing-masing level modulasi untuk perencanaan jaringan microcell LTE dengan menggunakan modulasi QPSK, 16-QAM, 64-QAM dan 256-QAM. Software simulasi yang diimplementasikan pada penelitian ini yakni software Atoll. Atoll merupakan suatu software radio planning yang menyediakan fitur-fitur yang komperhensif dan terpadu sehingga dapat digunakan untuk membuat proyek perencanaan microwave ataupun perencanaan radio dalam satu aplikasi. Parameter yang diukur pada pendekatan coverage adalah RSRP, CINR dan BER, sedangkan parameter yang diukur pada pendekatan capacity adalah throughput dan user connected.

Penelitian ini dilakukan di Pasar Glodok, profil wilayah pengamatan penelitian ini yakni kawasan Glodok yang merupakan salah satu pusat perdagangan DKI Jakarta khususnya terletak di Wilayah Kotamadya Jakarta Barat dan terbagi atas 8 Kecamatan yakni Kecamatan Taman Sari, Kecamatan Tambora, Kecamatan Grogol Petamburan, Kecamatan Palmerah, Kecamatan Kebon Jeruk, Kecamatan Kembangan, Kecamatan Cengkareng dan Kecamatan Kalideres. Kawasan pusat perdagangan Glodok sebagian besar terletak di Kecamatan Taman Sari termasuk lokasi Pasar Glodok. Pasar Glodok berlokasi di Jalan Glodok Selatan, Kecamatan Taman Sari tepatnya berada dipertigaan antara Jalan Gajah Mada dan Jalan Pancoran. Secara struktur organisasi Pasar Glodok berada dalam area 07 Glodok yang dibagi menjadi 11 pasar antara lain Pasar Glodok, Gang Kelinci, Ikan Luar Batang, Jembatan Lima, Kampung Duri, Muara Angke, Pasar Pagi, Penjangalan, Perniagaan, Pluit dan Teluk Gong. Akses untuk menuju Kawasan Pasar Glodok dapat melalui jalan utama sangat minim yakni untuk arah dari utara melalui Jalan Pintu Besar Selatan yang memutar melalui Jalan Hayam Wuruk, sedangkan dari arah selatan hanya dapat diakses dari Jalan Gajah Mada untuk kendaraan roda empat, sedangkan untuk kendaraan roda dua dan angkutan umum relatif cukup banyak jalan menuju Kawasan Pasar Glodok [5].

Perhitungan link budget digunakan untuk melakukan estimasi kebutuhan site pada suatu wilayah dengan metode daerah cakupan dan dilakukan dengan memperhatikan suatu perangkat jaringan dalam menjangkau wilayah layanan tersebut. Kondisi propagasi gelombang dari transmitter ke receiver tidak lepas dari pengaruh banyaknya redaman yang muncul akibat kondisi lintasan yang dilalui oleh gelombang. Hasil dari perhitungan disebut dengan Maximum Allowed Path Loss (MAPL), MAPL downlink maupun uplink dapat dihitung dengan persamaan berikut [6]:

$$
\begin{gathered}
M A P L=\text { EIRP-receiver sensitivity-interface margin }- \\
\text { penetration loss }- \text { fading margin }+ \\
\text { Rx antenna gain }- \text { body loss }
\end{gathered}
$$


AITI: Jurnal Teknologi Informasi

Effective Radiated Power (EIRP) merupakan daya transmit antena (PTx) yang dikurangi rugi-rugi transmisi (LTx) dan ditambah menjumlahkan gain antena transmisi (GTx) ke dalam bentuk daya keluaran sebenarnya dari transmitter [6]:

$$
\begin{gathered}
E I R P=\text { Tx power }(d B m)+T x \text { antenna gain }(d B i)+ \\
\text { Cable Losses } A P(d B)
\end{gathered}
$$

Hasil perhitungan EIRP menghasilkan 5,4 dBm untuk downlink, seperti pada Tabel 1.

Sensitivity receiver ditentukan dengan menjumlahkan nilai thermal noise, noise figure, dan SNR. Dalam menghitung thermal noise perlu memperhatikan konstanta Boltzman (K), temperatur (T) dan bandwidth (B) yang digunakan. Pada persamaan berikut ini digunakan untuk menghitung Sensitivity Receiver [6]:

$$
\begin{gathered}
\text { Receiver sensitivity }=\text { Thermal noise }(\mathrm{dBm})+ \\
\text { Noise figure }(d B)+\operatorname{SINR}(d B)
\end{gathered}
$$

Dimana nilai thermal noise didapatkan dari persamaan berikut:

$$
\text { Thermal noise }=10 \times \log (K \times T \times W)
$$

Hasil perhitungan Sensitivity Receiver ditunjukan pada Tabel 1.

Tabel 1. Hasil perhitungan sensitivity [7]

\begin{tabular}{lll}
\hline Parameter & Value & Unit \\
\hline Tx $($ NodeB $)$ & & \\
Tx power $(\mathrm{dBm})$ & 39 & $\mathrm{~A}$ \\
Tx antenna gain $(\mathrm{dBi})$ & 18 & $\mathrm{~B}$ \\
Cable Losses AP $(\mathrm{dB})$ & -3 & $\mathrm{C}$ \\
EIRP $(\mathrm{dBm})$ & 54 & $\mathrm{D}=\mathrm{A}+\mathrm{B}+\mathrm{C}$ \\
Rx $($ User Equipment) & & \\
UE Noise Figure $(\mathrm{dB})$ & 7 & $\mathrm{E}$ \\
Thermal Noise $(\mathrm{dBm})$ & $-32,0094183$ & $\mathrm{~F}=\mathrm{K} * \mathrm{~T} * \mathrm{~B}$ \\
Receiver Noise Floor $(\mathrm{dBm})$ & $-25,0094183$ & $\mathrm{G}=\mathrm{E}+\mathrm{F}$ \\
SINR $(\mathrm{dB})$ & 5,5 & $\mathrm{H}$ \\
Receiver Sensitivity $(\mathrm{dBm})$ & $-19,5094183$ & $\mathrm{I}=\mathrm{G}+\mathrm{H}$ \\
Interference Margin $(\mathrm{dB})$ & 4 & $\mathrm{~J}$ \\
Penetration Loss $(\mathrm{dB})$ & 12 & $\mathrm{~K}$ \\
Fading Margin $(\mathrm{dB})$ & 10 & $\mathrm{~L}$ \\
RX antenna Gain $(\mathrm{dB})$ & 0 & $\mathrm{M}$ \\
Body Loss $(\mathrm{dB})$ & 4 & $\mathrm{~N}$ \\
MAPL $(\mathrm{dB})$ & 143,5094183 & $\mathrm{D}-\mathrm{I}-\mathrm{J}-\mathrm{K}-\mathrm{L}+\mathrm{M}-\mathrm{N}$ \\
\hline
\end{tabular}

Pada perencanaan dengan frekuensi $1800 \mathrm{MHz}$, untuk LTE menggunakan model propagasi Cost 231-Hatta. Untuk persamaan model Cost 231-Hatta ditunjukkan pada persamaan berikut [6]:

$$
\begin{gathered}
L p=46,3+33,9(\log f c)-13,82 \log h T e-a(h m)+(44,9- \\
6,55 \log h T e) \log D+C M
\end{gathered}
$$




$$
a(h m)=(1,1 \log f c-0,7) h m-(1,56 \log f c-0,8)
$$

Keterangan :

fc $=$ frekuensi transmisi $(1500-2000 \mathrm{MHz})$.

$\mathrm{hTe}=$ tinggi antena eNodeB

$\mathrm{hm} \quad=$ tinggi antena UE

$\mathrm{a}(\mathrm{hm})=$ faktor koreksi antar antena UE.

$\mathrm{D}=$ jarak antara eNodeB dengan UE $(1 \mathrm{~km}-20 \mathrm{~km})$.

$\mathrm{CM}=0 \mathrm{~dB}$ untuk kota menengah dan kota sub urban. Untuk daerah pusat kota (metropolitan) sebesar $3 \mathrm{~dB}$

Model propagasi Cost 231-Hatta lebih tepat diaplikasikan untuk perencanaan jaringan LTE dengan frekuensi $1800 \mathrm{MHz}$.

Jumlah eNodeB pada perancangan berdasarkan area cakupan dihitung sesuai dengan luas daerah perencanaan. Perhitungannya mengasumsikan penggunaan site 3 sektoral menggunakan persamaan sebagai berikut [6]:

$$
\text { Lsel }=2,6 \times d^{2}
$$

Perhitungan capacity planning digunakan untuk mengestimasi banyaknya user dalam satu sel yang dapat tercakup. Pada perhitungan kapasitas ini mempertimbangkan kebutuhan layanan tiap user pada suatu daerah, kebutuhan layanan tiap user akan selalu berbeda di setiap daerah.

Langkah awal untuk menentukan forecasting jumlah pelanggan yakni mengetahui faktor pertumbuhan user hingga tahun ke-n. Pada penelitian ini hanya menggunakan 1 tahun sehingga untuk faktor pertumbuhan user mengggunakan jumlah user pertahun yakni 15.000 penduduk. Selanjutnya mengetahui total target user. Total target user berfungsi untuk mengetahui jumlah user yang menggunakan operator X dari keseluruhan jumlah user yang ada. Persamaan total target user dapat dihitung sebagai berikut menggunakan persamaan berikut [8]:

$$
\text { Total target user }=P n \times A \times B \times C
$$

Menentukan trafik dan model layanan yakni menghitung jumlah throughput pada masing-masing layanan di LTE. Tujuan menghitung nilai throughput di masing-masing layanan yakni mengetahui minimal throughput yang dibutuhkan di tiap layanan agar suatu layanan dapat tetap berjalan. Berikut contoh perhitungan untuk mengetahui nilai throughput di tiap layanan dengan menggunakan persamaan berikut [7]:

Throughput $=$ bearer rate $\times$ session time $\times$ session duty ratio $\times$

$$
\left[\frac{1}{1-B L E R}\right]
$$


AITI: Jurnal Teknologi Informasi

Keterangan :

Bearer Rate $=$ kecepatan bearer layanan pada layer aplikasi.

Session Time $=$ lama durasi tiap sesi layanan.

Session Duty Ratio = rasio kecepatan transmisi tiap layanan.

BLER = Block Error Rate.

Nilai-nilai tersebut sesuai dengan parameter standar berdasarkan referensi Huawei [9].

Traffic model digunakan sebagai penentu perkiraan kebutuhan trafik user. Terdapat dua parameter yakni penetration rate dan busy hour service attempt (BHSA). Penetration rate digunakan untuk menunjukaan proporsi dari tiap layanan dan busy hour service attempt digunakan untuk sesi percobaan tiap user pada tiap layanan. Untuk mempermudah perhitungan, trafik model yang digunakan berdasarkan standarisasi dari Huawei [9].

Perhitungan network throughput dilakukan untuk mengetahui kebutuhan kapasitas jaringan. Sebelum menghitung network throughput, terlebih dahulu menghitung beberapa parameter seperti peak to average ratio, cell capacity dan single user throughput. Peak to average ratio merupakan asumsi presentasi tertinggi untuk lonjakan trafik di jaringan dalam kondisi dan waktu tertentu. Peak to average ratio ini memiliki nilai yang berbeda-beda pada tiap dareah hal ini karena semakin padat suatu wilayah maka semakin tinggi asumsi lonjakan trafiknya, parameter ini dimaksudkan untuk mengantisipasi lonjakan trafik di jaringan yang akan direncanakan. Single user throughput merupakan suatu parameter yang menunjukan total throughput yang didapatkan oleh satu user dengan menggunakan beberapa layanan tertentu. Perhitungan single user throughput dapat dihitung dengan menggunakan formula sebagai berikut [7]:

$$
\begin{gathered}
\text { Single User Throughput }=\left[\sum\left(\frac{\text { throughput }}{\text { session }}\right) \times B H S A \times\right. \\
\text { Penetration ratio } \times(1+\text { Peak to averation })]
\end{gathered}
$$

Keterangan:

BHSA = service attempt in busy hour

Penetration rate $=$ penetrasi jaringan tiap daerah

Peak to Average Ratio = penetrasi rata-rata tiap daerah

Penetration rate dapat dilihat pada Tabel 2. 
Tabel 2. Peak to average ratio [9]

\begin{tabular}{llllc}
\hline Morphology & Dense Urban & Urban & Sub Urban & Rural \\
\hline Peak to Average Ratio & $40 \%$ & $20 \%$ & $10 \%$ & $0 \%$ \\
\hline
\end{tabular}
yaitu [9]:

Langkah selanjutnya dalam menghitung parameter network throughput

$U L / D L$ network throughput $(I P)=$ total user number $\times U L / D L$ single user throughput

Nilai total network throughput yang didapatkan merupakan nilai throughput pada layer IP yang harus dikonversikan terlebih dahulu agar mendapatkan nilai throughput pada layer MAC, karena throughput yang akan diperoleh user adalah throughput pada layer MAC. Perhitungan throughput pada layer MAC dari sisi downlink dan uplink dapat menggunakan persamaan berikut [9].

Total network throughput (MAC layer $)=$

Total network throughput (IP)/AxBxC

Dimana $(\mathrm{A} \times \mathrm{B} \times \mathrm{C})$ didapatkan dari perkalian relative efficiency packet, dapat dilihat berdasarkan Tabel 5 berikut.

Tabel 5. Relative efficiency packet [9]

\begin{tabular}{llll}
\hline Protokol Layer & Average Packet & Relative Effeciency & Simbol \\
\hline PDCP & 302 & 0,993377483 & $\mathrm{~A}$ \\
RLC & 304 & 0,993421053 & $\mathrm{~B}$ \\
MAC & 306 & 0,993464052 & $\mathrm{C}$ \\
\hline
\end{tabular}

Setelah mendapatkan nilai dari network throughput, perhitungan cell capacity perlu dilakukan hal ini bertujuan untuk mengetahui kapasitas yang dibutuhkan sesuai dengan total network throughput yang telah didapatkan pada perhitungan sebelumnya. Perhitungan cell capacity dapat dihitung menggunakan formula sebagai berikut [9]:

$$
\begin{gathered}
D L \text { cell capacity }-C R C=(N R E-N c R E-N r R E) \times(\text { code bit }) \times \\
(\text { code rate }) \times N r b \times C \times 1000 \\
\begin{array}{l}
\text { cell capacity }-C R C=(N R E-N r R e U L) \times(\text { code bit }) \times \\
(\text { code rate }) \times N r b \times C \times 1000
\end{array}
\end{gathered}
$$

Keterangan :

UL throughput $=$ Uplink layer throughput.

DL throughput $=$ Downlink layer throughput.

CRC = Cyclic Redundancy Check (24 bit).

$N R E=$ jumlah resource element dalam 1ms (168). 
AITI: Jurnal Teknologi Informasi

NCRE = jumlah control channel RE dalam $1 \mathrm{~ms}$ (36).

$N r R E=$ jumlah reference signal $R E$ dalam $1 \mathrm{~ms}$ (12).

NrREUL = jumlah reference signal RE dalam 1 ms pada uplink (24).

Code bit = modulation efeciency.

Code rate $=$ channel coding rate

$\mathrm{Nrb}=$ jumlah resource blok yang akan digunakan.

$\mathrm{C}=$ mode antena MIMO.

Untuk nilai code bit dan code rate, sesuai dengan penggunaan modulasi. Sebagaimana pada Tabel 6 merupakan skema mapper modulasi.

Tabel 6. Parameter skema mapper modulation dan SINR [10]

\begin{tabular}{llll}
\hline Modulation & Code bit & Code rate & SINR (dB) \\
\hline QPSK & 2 & $1 / 3$ & 0 \\
QPSK & 2 & $1 / 2$ & 1,5 \\
QPSK & 2 & $2 / 3$ & 4,0 \\
QPSK & 2 & $3 / 4$ & 5,0 \\
QPSK & 2 & $4 / 5$ & 5,5 \\
16 QAM & 4 & $1 / 2$ & 7,0 \\
16 QAM & 4 & $2 / 3$ & 10,0 \\
16 QAM & 4 & $3 / 4$ & 11,5 \\
16 QAM & 4 & $4 / 5$ & 13,0 \\
64 QAM & 6 & $2 / 3$ & 15,0 \\
64 QAM & 6 & $3 / 4$ & 17,0 \\
64 QAM & 6 & $4 / 5$ & 18,5 \\
256 QAM & 8 & $2 / 3$ & 20,0 \\
256 QAM & 8 & $3 / 4$ & 22,0 \\
256 QAM & 8 & $4 / 5$ & 24,0 \\
256 QAM & 8 & $7 / 8$ & 27,0 \\
\hline
\end{tabular}

Untuk mengetahui baik atau tidaknya hasil dari simulasi, maka dapat dilihat pada parameter tabel berikut ini yang menjadi dasar parameter hasil simulasi:

\section{RSRP ( Reference Signal Received Power )}

RSRP merupakan power dari sinyal yang di terima dari eNodeB ke UE.

Semakin dekat dengan serving sit, semakin baik kuat sinyal yang diterima oleh user. Akan tetapi apabila saat menjauh dari coverage serving site semakin buruk kuat sinyal yang diterima oleh user. Tabel 7 menunjukkan kriteria RSRP.

Tabel 7. Standar KPI RSRP [6]

\begin{tabular}{ll}
\hline Category & Range Nilai RSRP $(\mathbf{d B m})$ \\
\hline Good & -70 to -90 \\
Normal & -91 to -110 \\
Bad & -110 to -130 \\
\hline
\end{tabular}


2. Throughput dan user connected

Throughput memiliki satuan bit per second (bps) dengan jumlah throughput yang merupakan jumlah rata-rata dari bit yang telah berhasil diterima semua terminal pada sebuah jaringan dan user connected merupakan salah satu parameter yang mengukur jumlah user yang telah tersambung atau mengakses layanan dari total keseluruhan user yang ada [6].

\section{Hasil dan Pembahasan}

Simulasi coverage dilakukan dengan memasukan parameter-parameter jaringan di setiap transmitter yang telah diatur pada software Atoll. Simulasi ini dipengaruhi beberapa faktor diantaranya adalah kontur bumi dan clutter classes selain itu spesifikasi perangkat yang digunakan juga dapat mempengaruhi hasil simulasi ini. Pada simulasi ini parameter yang akan diuji yakni RSRP (Reference Signal Received Power), CINR (Carrier to Interference and Noise Ratio) dan BER (Bit Error Rate).

Pada teknologi LTE, parameter RSRP didefinisikan sebagai rata-rata linear pada resource element yang membawa informasi reference signal pada resource block dalam rentang bandwidth yang digunakan. Parameter ini berfungsi memberikan informasi kepada UE, mengenai kuat sinyal yang diterima oleh UE terhadap serving cell yang melayani UE tersebut. Selain itu, digunakan untuk menentukan kelayakan perencanaan LTE terhadap parameter coverage. Kriteria kuat sinyal dapat dilihat pada Tabel 7.

Dalam penelitian ini dapat dilihat dari histogram di atas bahwa nilai RSRP masuk pada kategori normal coverage. Dari simulasi 1 hingga simulasi 4 dengan penggunaan modulasi QPSK, 16-QAM, 64-QAM dan 256-QAM nilai rata-rata RSRP tidak mengalami perubahan. Hal ini karena, power sinyal akan selalu menyesuaikan dengan penggunaan modulasi. Dapat dilihat pemakaian modulasi tertinggi pada penelitian ini yakni penggunaan modulasi hingga 256-QAM. Modulasi 256-QAM memiliki daya sinyal yang maksimal karena membawa bit semakin besar yakni 8 bit per simbol akan tetapi area cakupan semakin kecil. Begitu juga dengan penggunaan modulasi terkecil pada penelitian ini yakni modulasi QPSK memiliki daya sinyal yang kecil karena hanya membawa informasi sebesar 2 bit per simbol dan memiliki area cakupan yang luas. Sehingga parameter RSRP tidak terjadi perubahan untuk penggunan level modulasi pada penelitian ini. Namun penggunaan modulasi akan mempengaruhi area cakupan, semakin besar bit simbol yang dikirimkan maka area cakupan semakin kecil dan begitu juga sebaliknya. 


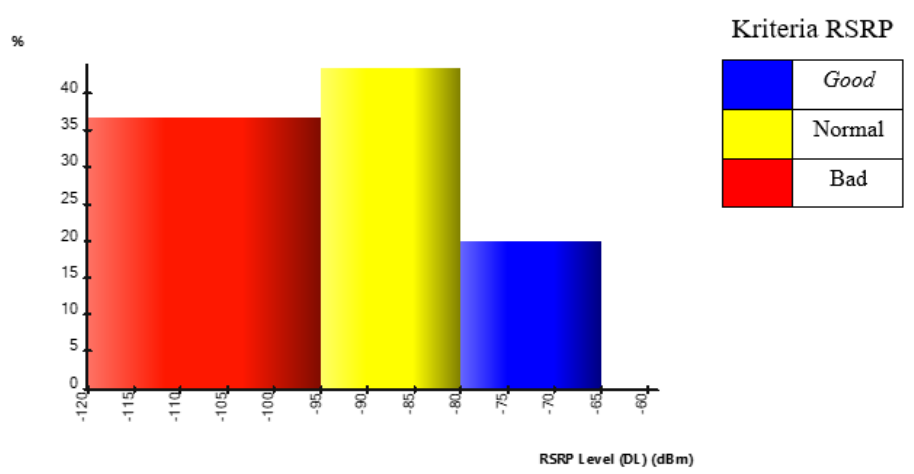

Gambar 1. RSRP untuk semua level modulasi

Parameter CINR digunakan untuk mengetahui daya signal carrier terhadap daya sinyal penginterferensinya. Pada simulasi ini dapat terlihat kualitas suatu sel yang mencakup suatu area. Parameter CINR memiliki bebarapa tingkatan rentang nilai, dikatakan very good apabila memiliki rentang nilai lebih dari $25 \mathrm{dBm}$, dikatakan good apabila memiliki rentang nilai $15 \mathrm{dBm} \geq \mathrm{CINR}$ level $\leq 25 \mathrm{dBm}$, dikatakan average apabila memiliki rentang nilai sebesar $5 \mathrm{dBm} \geq \mathrm{CINR}$ level $\leq 15$ $\mathrm{dBm}$ dan dikatakan bad apabila memiliki rentang nilai CINR level $\leq 5 \mathrm{dBm}$.

Dalam penelitian ini dibuat skenario 4 simulasi. Simulasi 1 menggunakan modulasi QPSK, simulasi 2 menggunakan modulasi hingga 16-QAM, simulasi 3 menggunakan modulasi hingga 64-QAM dan simulasi 4 menggunakan modulasi hingga 256-QAM. Sebagaimana tertera pada Gambar 2 dan 3 yang menunjukkan bahwa hasil simulasi persebaran CINR, untuk rata-rata CINR pada simulasi 1 dan 2 sebesar 1,2 dBm dan 4,1 dBm. Sehingga untuk nilai CINR pada simulasi 1 dan 2 termasuk rentang bad karena kurang dari $5 \mathrm{dBm}$. Sedangkan Gambar 4 dan 5 yang menunjukkan bahwa hasil simulasi persebaran CINR untuk rata-rata CINR pada simulasi 3 dan 4 sebesar $6,4 \mathrm{dBm}$ dan $8,5 \mathrm{dBm}$ yang berarti termasuk dalam rentang average.

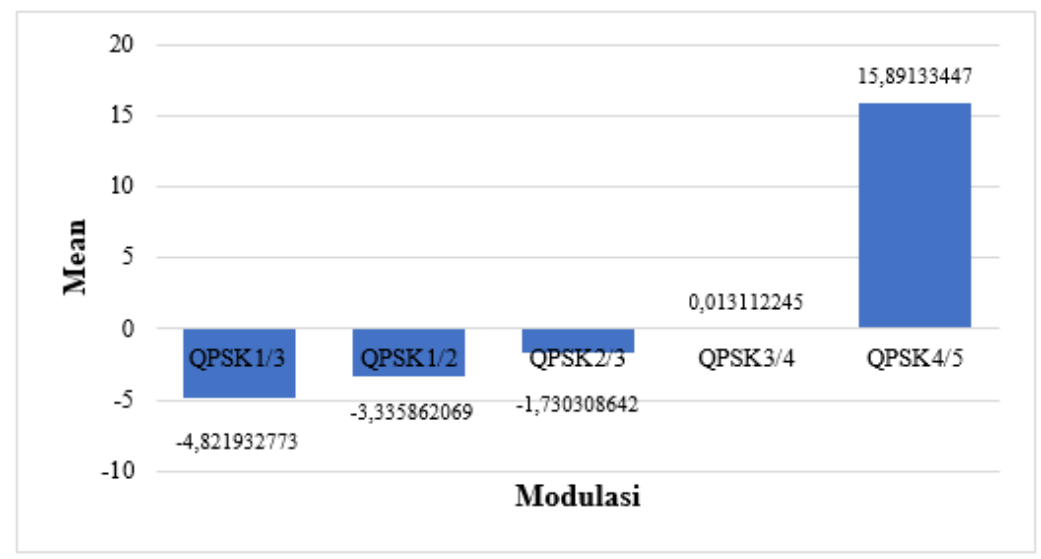


Gambar 2. Coverage by CINR QPSK

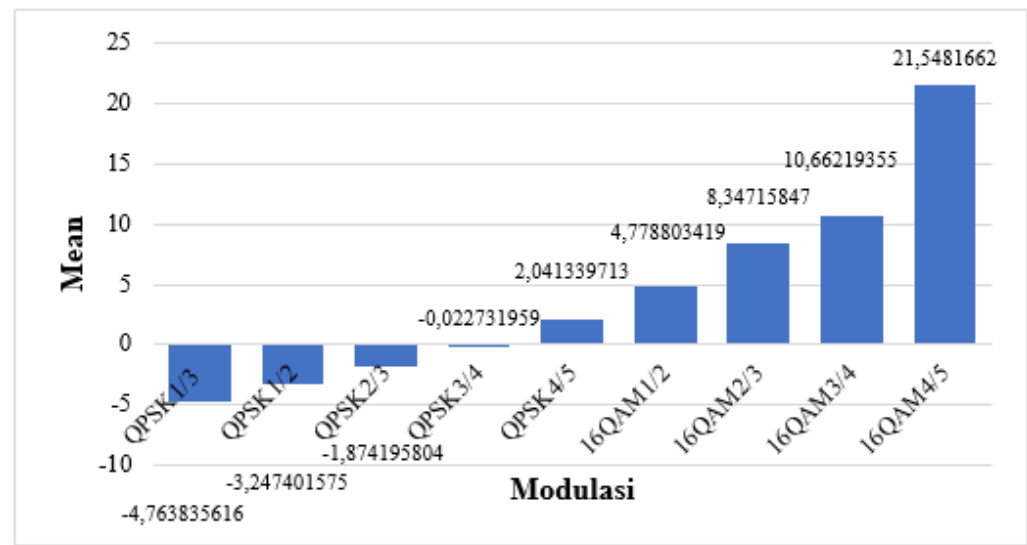

Gambar 3. Coverage by CINR 16-QAM

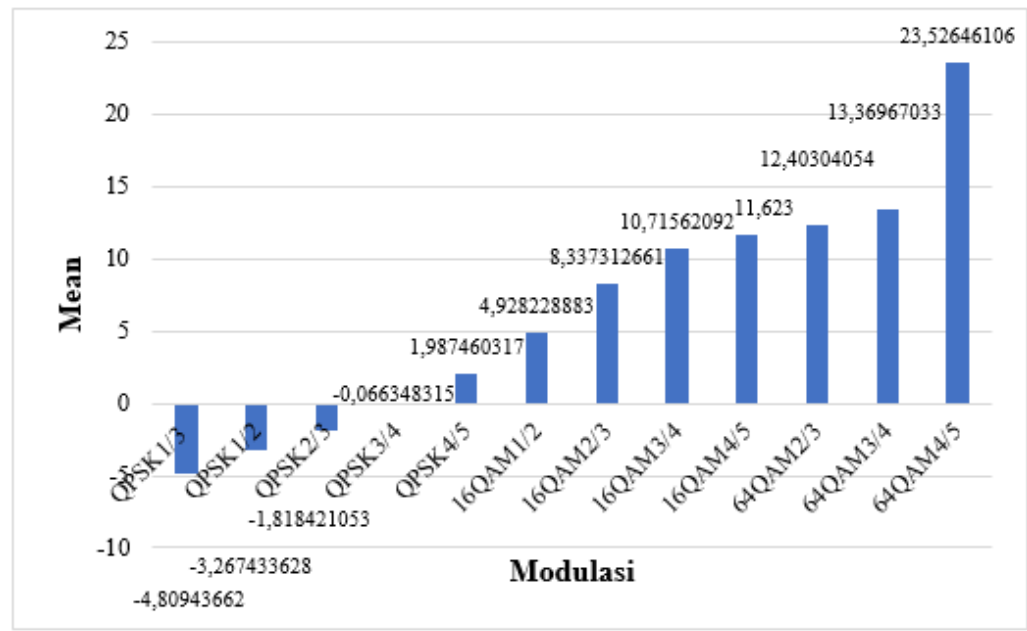

Gambar 4. Coverage by CINR 64-QAM

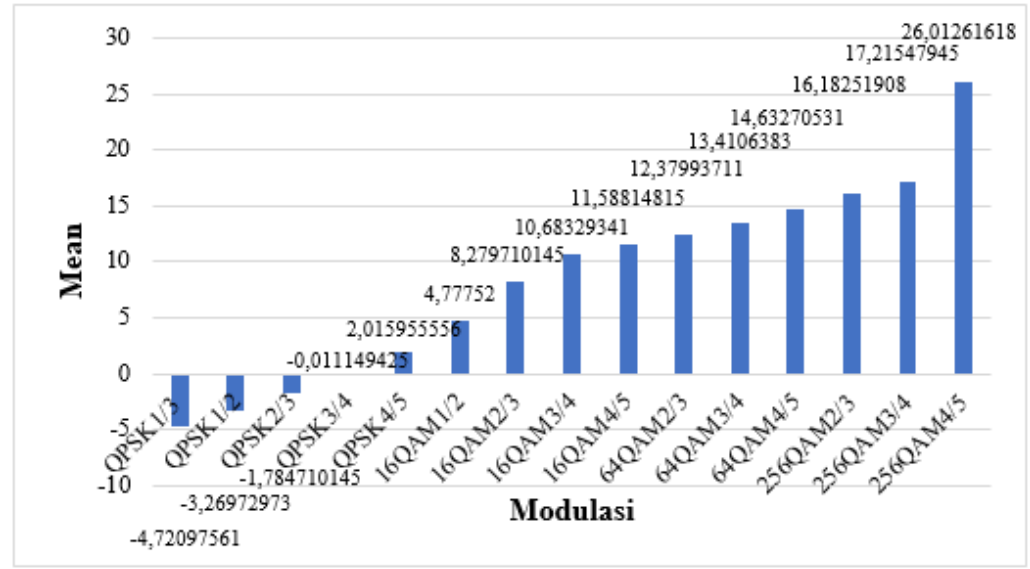

Gambar 5. Coverage by CINR 256-QAM

Parameter BER digunakan untuk mengetahui perbandingan jumlah bit yang error yang diterima oleh receiver terhadap jumlah bit yag dikirim. BER 
dipengaruhi oleh noise. Pada penelitian ini menggunakan 4 tingkatan modulasi yakni QPSK, 16-QAM, 64-QAM dan 256-QAM. Sebagaimana tertera pada Gambar 4.6 untuk penggunaan modulasi QPSK memiliki nilai BER yang lebih kecil yaitu sebesar 0,1 dibandingkan dengan modulasi lainya yang digunakan pada penelitian ini, dan dapat dilihat untuk modulasi 16-QAM, 64-QAM dan 256-QAM memiliki nilai BER yang sama yaitu sebesar 0,13 . Hal ini karena nilai BER tidak berpengaruh pada bit per simbol yang dikirim pada masing-masing modulasi, hanya saja berpengaruh terhadap jenis modulasi, yakni modulasi PSK dan QAM.

Modulasi QPSK merupakan salah satu jenis modulasi PSK. Modulasi PSK (Phase shift keying) adalah modulasi digital yang membawa data dengan merubah fase dari sinyal referensi (sinyal carrier). Pada modulasi PSK, tiap bit akan membentuk simbol yang diwakili oleh fase yang berbeda satu dengan lainnya. Pada modulasi QPSK, tiap bit akan membentuk simbol yang diwakili oleh fase yang berbeda satu dengan lainnya. Sedangkan modulasi 16-QAM, 64-QAM dan 256QAM merupakan salah satu dari jenis modulasi QAM. Modulasi QAM (Quadrature amplitude modulation) merupakan skema modulasi yang membawa data dengan merubah amplitudo dan fase dari sinyal carrier. Sinyal yang dimodulasi akan menghasilkan sinyal modulasi yang merupakan kombinasi dari PSK (phase shift keying) dan ASK (amplitude shift keying).

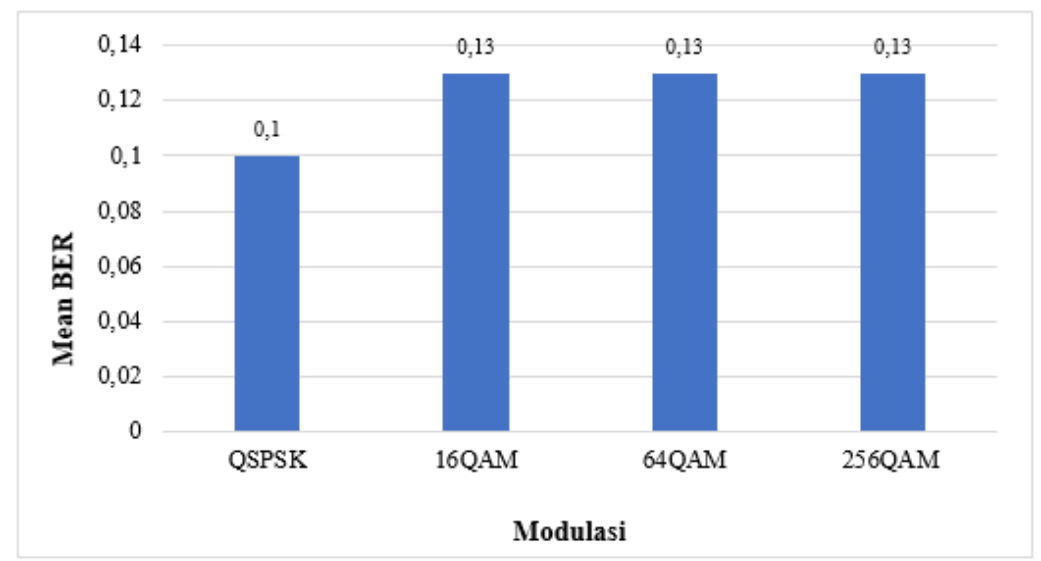

Gambar 6. Hasil simulasi coverage by BER

Simulasi user connected bertujuan mengetahui kemampuan dari suatu jaringan dalam melayani user yang akan mengakses layanan pada jaringan tersebut. Dalam sisi parameter throughput, digunakan nilai rata-rata throughput. Nilai throughput akan bervariasi sesuai dengan penggunaan modulasi. Apabila penggunaan tingkat modulasi semakin tinggi maka berakibat throughput yang didapatkan juga semakin tinggi. 


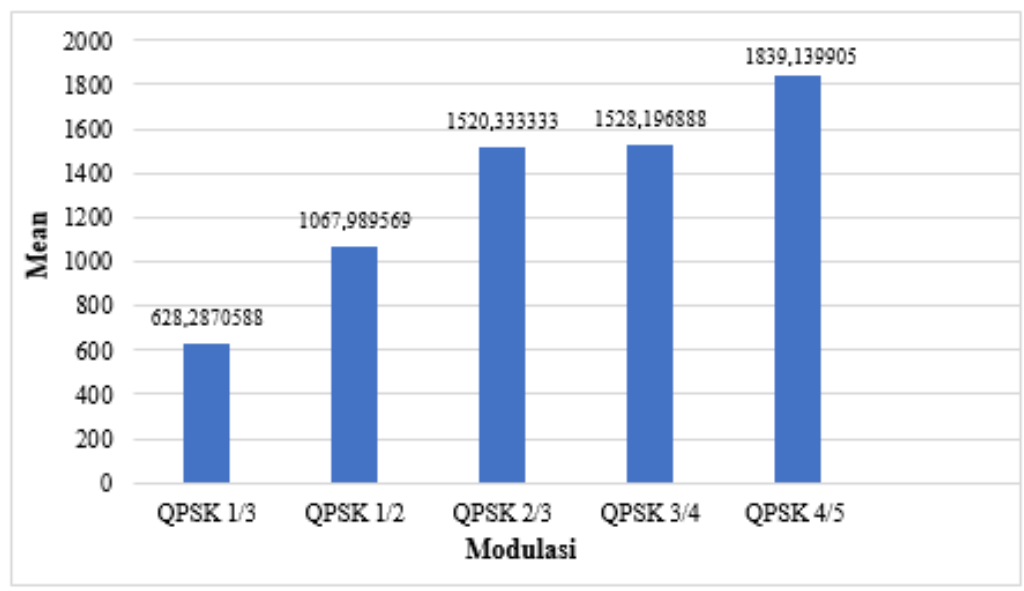

Gambar 7. Hasil persebaran nilai throughput QPSK

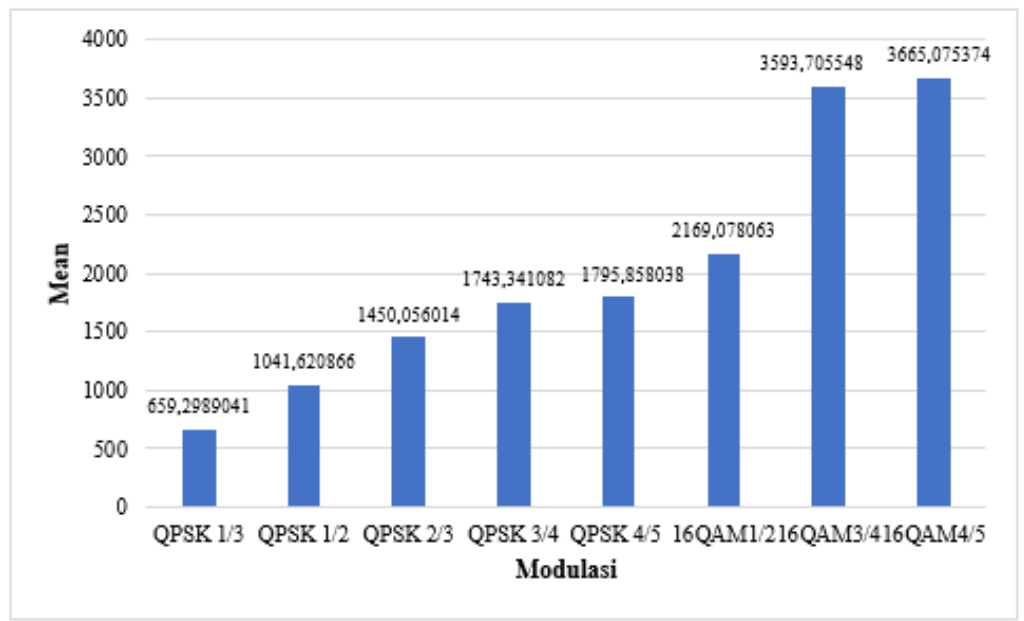

Gambar 8. Hasil persebaran nilai throughput 16-QAM

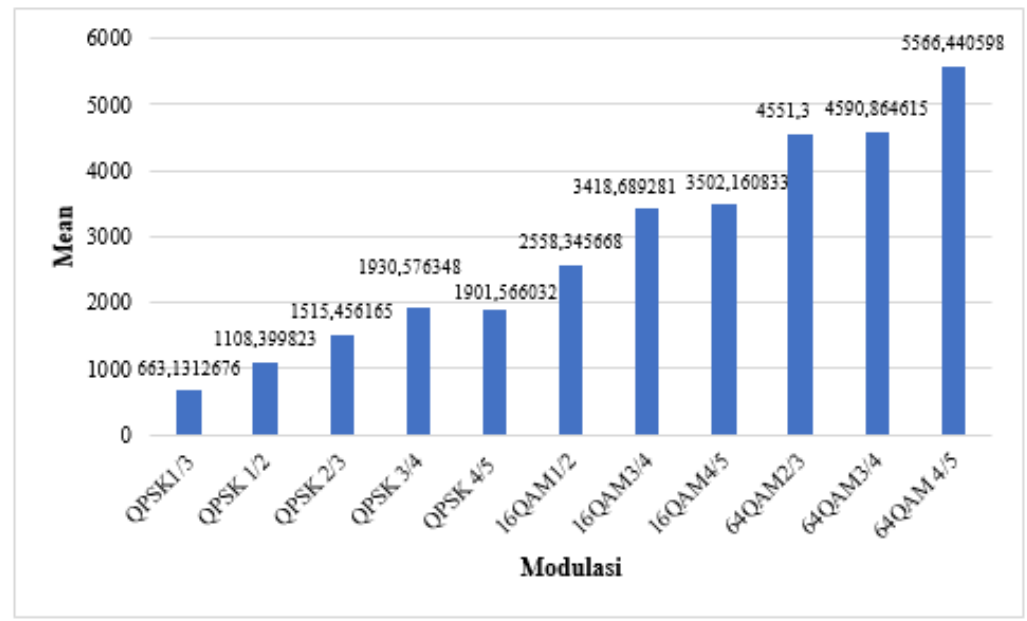

Gambar 9. Hasil persebaran nilai throughput 64-QAM 


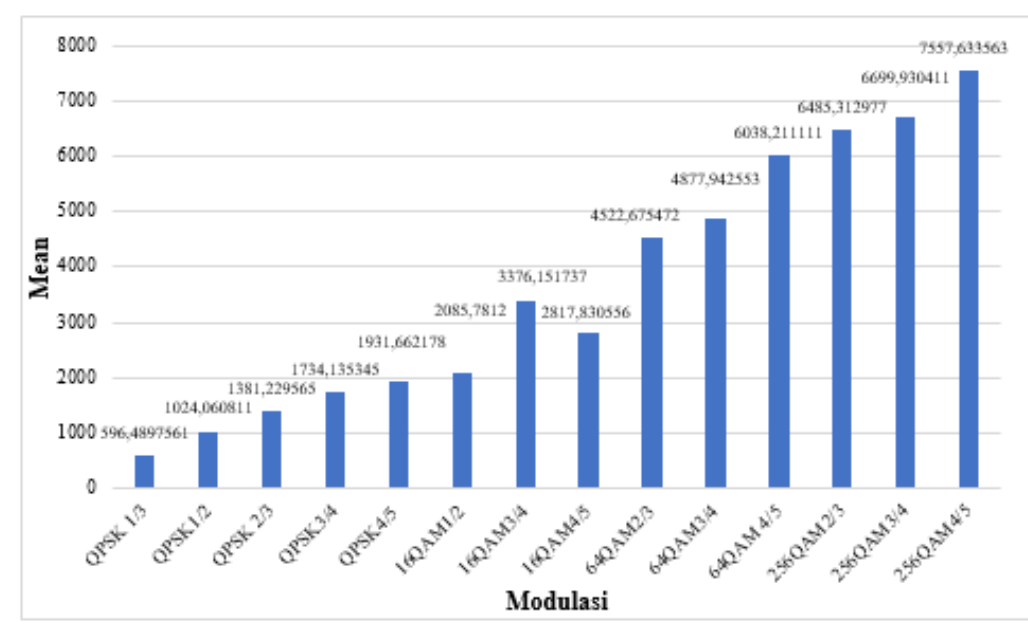

Gambar 10. Hasil persebaran nilai throughput 256-QAM

Tabel 8. Rekap hasil keseluruhan capacity berdasarkan user connected dan rata-rata throughput

\begin{tabular}{llll}
\hline Pemakaian modulasi & No coverage & User connected & $\begin{array}{c}\text { Rata-rata throughput } \\
\text { (Kbps) }\end{array}$ \\
\hline QPSK & 1,7 & $100 \%$ & 1316,789 \\
16QAM & 1,6 & $100 \%$ & 2014,754 \\
64QAM & 1,1 & $100 \%$ & 2846,05 \\
256QAM & 0,9 & $100 \%$ & 3652,075 \\
\hline
\end{tabular}

Dapat dilihat pada hasil nilai throughput semakin besar modulasi dan code rate yang digunakan maka semakin besar throughput yang dihasilkan.

\section{Simpulan}

Berdasarkan hasil simulasi, penggunaan variasi level modulasi pada simulasi coverage by RSRP selalu menyesuaikan dengan penggunaan berapapun level modulasi yang digunakan. Sedangkan berdasarkan hasil simulasi untuk mendapatkan data rate yang lebih tinggi maka diperlukan nilai CINR yang lebih tinggi. Hasil simulasi berdasarkan capacity by user connected, penggunaan level modulasi yakni QPSK, 16-QAM, 64-QAM dan 256-QAM mampu malayani semua user sehingga nilai user connected yang didapatkan dari keempat modulasi tersebut mencapai $100 \%$. Sedangkan berdasarkan hasil simulasi capacity by throughput, nilai throughput tertinggi dihasilkan oleh pemakaian modulasi hingga 256-QAM yakni sebesar 3652,075 Kbps disusul dengan pemakaian modulasi hingga 64-QAM sebesar 2846,05 Kbps, modulasi 16-QAM sebesar 2014,754 Kbps dan terakhir penggunaan modulasi QPSK yaitu sebesar 1316,789. Hal ini dikarenakan, meskipun modulasi 256-QAM dapat mengirimkan informasi sebanyak 8 bit per symbol. Akan tetapi modulasi 256-QAM tidak tahan terhadap interferensi, sehingga dihasilkan nilai throughput paling tinggi dibandingkan dengan penggunaan modulasi lain dalam penelitian ini. 


\section{Daftar Pustaka}

[1] D. S. Setiawan, Analisis Perancangan dan Performansi LTE Femtocell di Gedung A dan B Telkom University, vol. 3, no. 2, p. 1509, Agustus 2016.

[2] Alfin Hikmaturokhman, Fitri Kemala Utami;, "Perencanaan Femtocell 4G LTE 1800 Mhz Studi Kasus Gedung baru ST3 Telkom Purwokerto," in Proceedings Seminar Nasinal Teknik Elektro, 2016.

[3] Unit Laboratorium Fakultas Ilmu Terapan, "Atoll RF Planning," 8 May 2017. [Online]. Available: fit.labs.telkomuniversity.ac.id.

[4] Rivan Achmad Nugroho, Hurianti Vidyaningtyas, Uke Kurniawan Usman, "Perencanaan Jaringan Mikrosel 4G LTE di Skywalk Cihampelas Bandung," e-Proceeding of Engineerin, vol. 5, no. 1, p. 782, Maret 2018.

[5] Iwan Indrayanto, "Pasar Glodok," Program Pacsasarjana, Universitas Indonesia, 2008.

[6] Alfin Hikmaturohkman, dkk, 4G Handbook Edisi Bahasa Indonesia, www.nulisbuku.com, 2014.

[7] Huawei Technologies co.Ltd, "LTE Radio Network Coverage Dimensioning," 2013.

[8] Uke, Galuh dkk, Fundamental Teknologi Seluler LTE, Rekayasa Sains,Indonesia, 2013.

[9] Huawei Technologies co.Ltd., "LTE Radio Network Planning Introduction," 2010.

[10] Kazuki Maruta, "Experimental Verification of Null-Space Expansion for Multiuser Massive MIMO via Channel State Information Measurement," IEICE Transactions on Communications, March 2018. 